\title{
Professor William Bynum: Academic Pioneer, Role Model and Dear Friend
}

\author{
ANDREW SCULL* \\ Sociology and Science Studies, University of California, San Diego, USA
}

I vividly remember the first time I met Bill Bynum. The American Council of Learned Societies had given me a post-doctoral fellowship, and I arrived in 1976 at what was then the sub-Department of the History of Medicine, located in a handful of rooms next to the Department of Anatomy in the godless institution on Gower Street. I entered that warren in search of my quarry and found two rooms more filled with books than any I had ever seen, spilling out of the shelves, piled on the floor, threatening the engulf the office's occupant, a then-young, bearded, transplanted Texan with an odd mid-Atlantic accent. It was the beginning of a treasured friendship that has endured to this day.

Bill's small unit was a hive of activity, a friendly, intellectually stimulating place that became my home for the year. By the time of my next extended visit in 1981, it had transferred to the Wellcome Building on Euston Road, and was being transformed under his expert guidance into the global hub of the discipline of medical history. It is easy, towards the end of one's career, to lapse into a sense of nostalgia for lost Golden Ages, but in this case, Bill's leadership really did create something quite remarkable. For two decades, the Wellcome Institute became the place where everyone in the field gathered. It was there, not on their own continent, that many North American scholars ran into one another. Europeans flocked to its intellectual riches too. And neophytes as well as established scholars found it the most congenial and intellectually stimulating place to be, with all manner of seminars to attend, the immense riches of the Wellcome Library to work with, and conversations with the talented academics who joined Bill's unit besides. In my own specialised field, for example, the history of psychiatry, Bill and Roy Porter, with the assistance of that most atypical of psychiatrists Michael Shepherd, organised a stunning series of bi-weekly seminars that stretched over two years, an intellectual treat that did much to establish the field as the flourishing enterprise it has remained ever since. The three Anatomy of Madness volumes ${ }^{1}$ have preserved much of the formal scholarship that resulted from those occasions, but they only hint at the intellectual excitement the sessions themselves produced, and their importance in establishing a new field of scholarship.

None of this happened by accident, of course. It took an enormous amount of behind the scenes work and effort to create the rich intellectual feast we all enjoyed. Visitors to Bill's office would have assumed that he could not have been the driving force behind the smooth-running enterprise. A sign on the door read 'a clean desk is the sign of a sick

*Email address for correspondence: ascull@ucsd.edu

${ }^{1}$ W.F. Bynum, R. Porter and M. Shepherd (eds) The Anatomy of Madness, Vols 1 and 2 (London: Tavistock, 1985); Vol. 3 (London: Routledge, 1986). 
mind' and despite his relocation to larger, more elegant premises, the chaos within still reminded me of his UCL space: books and papers everywhere, on the floor, on top of file cabinets, on desks that demonstrated that its occupant was determined not to be accused of mental illness. On a corner of one of the surfaces, there was always a chess board, part of a long-running series of battles with Roy Porter which had once been conducted by post, and still persisted, despite their now being in adjacent offices. All the stray paper was in part the product of still another role Bill was busy with in these years, editing, with Vivian Nutton, the journal Medical History, and making it a venue for some of the most important new scholarship that appeared in the last quarter of the twentieth century. Notable, too, was a remarkable review section, one that reflected Bill's own deep love of books.

Bill does not suffer fools or sociologists gladly. (I'm not sure that he doesn't think that the latter are a subset of the former.) Somehow, I escaped the censure, perhaps because I share the dislike of sociological jargon and pretense, but perhaps for a deeper intellectual reason. For the reality is, despite Bill's needling about the excesses of 'social constructionism', his vision of medical history is, beneath its surfaces, one that embraces the centrality of social and cultural context to the study of the medical enterprise. Placing the intellectual and the technical in a social-historical perspective is for him an inescapable part of any serious scholarly attempt to examine the Western medical tradition. That does not mean, of course, that the intellectual and the technical can be taken for granted, or treated as epiphenomenal. On the contrary, Bill was and is equally committed to promoting a rigorous and critical interrogation of medicine's epistemology and its practices. Neither the social nor the scientific were or are unproblematic, and neither in isolation made or makes for the sort of rich historical understanding of disease and its histories that the best work should aim to provide. Mythological histories of great men and women and their discoveries were, so those working at the Institute showed, emphatically not the model to be emulated. It was that stimulating and broad church vision of medical history that the Wellcome Institute (as it then was) did so much to foster in the more than two decades that Bill was at the helm - aided, it must be said, by the talented and varied array of academics whom he attracted to form its permanent staff, and whose careers his behind the scenes efforts did so much to advance.

Its metropolitan location and its wonderful bibliographic and inconographic resources obviously played a vital part in the Wellcome Institute's scholarly prominence in those years. But no-one should underestimate how much we - and the Wellcome Trust - owe to Bill Bynum for ensuring that on that solid foundation, and with indispensable assistance from the generosity of Henry Wellcome, medical history began to flourish in London as never before.

Much has changed since Bill's retirement, but recent developments suggest that there is every reason to be optimistic about the future for medical historical research. The journal he edited for so long continues in excellent health, now under the guidance of a dynamic new editor, who is supported by a grand cast of advisors drawn from all over the world - a constant reminder to future generations of all that Bill achieved. Funding for research in the history of medicine is stable (and possibly increasing). The Wellcome Trust have instituted a new series of Investigator Awards that represents a wonderful way of underwriting serious scholarship from academics at the top of their game. On still another front, moves appear afoot to create a new research hub likely to be associated with the Wellcome Library, something that will help to ensure its continued intellectual vitality and to reinforce its central importance to all of us who work in the discipline. 
Others, of course, deserve much of the credit for the imaginative leadership and the hard work associated with these recent developments. But in a wider perspective, the renewed energy that seems to mark the discipline necessarily builds upon the extraordinary legacy Bill Bynum left behind. On second thoughts, that sounds too elegiac, for his contributions continue. 'Retirement' has simply meant that, freed at last from all the burdens he so willingly assumed for decades, Bill is able to write without all the distractions that used to waylay him (ducks and gardening excepted), and he continues to be a prolific contributor to the field, often with his wife Helen.

Medical history in Britain, and indeed on a broader canvass, owes an enormous debt to Bill Bynum. His erudition and intellectual range, the depth of his knowledge and of his commitment to building the discipline - training along the way many first-rate academics - have left a lasting imprint on the field. We do well to honour the person and his contributions. As to the form that recognition takes, I do not think it stretches things to say that the man is obsessed by books and the knowledge that is contained within them. What could be more fitting, therefore, than to establish an essay prize in his name? The annual William Bynum Prize, to be awarded by Cambridge University Press, on behalf of Medical History. 